\title{
О КРЕПОСТНЫХ СООРУЖЕНИЯХ СВИЯЖСКА
}

\section{(C) 2020 г. А.М. Губайдуллин, Р.Н. Хамзин}

В статье рассматриваются некоторые аспекты, касающиеся фортификации известного поселениякрепости, первоначально названого Новым городом Свияжским, а затем Свияжском. Он сыграл немаловажную роль в подготовке и завоевании Казани Иваном IV Грозным. Основанный в 1551 году в устье р. Свияга, этот укрепленный пункт явился местом сосредоточения русских войск и необходимых припасов для последующей осады столицы Казанского ханства, являясь опорным «лагерем» для вторжения. Несомненно, что для защиты этого создаваемого поселения должны были предприниматься серьезные мероприятия оборонительного характера на случай нападения противника. В связи с этим, интересным источником для нас является русская Летописная история XVI века. В ней кратко отражены подготовка и строительство данного объекта, что послужило первоначальным источником наших знаний об этом укрепленном поселении. Кроме того, в статье приводятся новые данные археологии, касающиеся оборонительных сооружений Свияжска середины XVI века.

Ключевые слова: археология, Среднее Поволжье, средневековье, крепость Свияжск, фортификация.

\section{THE FORTRESS STRUCTURES OF SVIYAZHSK}

\section{A.M. Gubaidullin, R. N. Khamzin}

The article considers a series of aspects related to the fortification a renowned fortress settlement, originally referred to as the New Town of Sviyazhsk, and later as Sviyazhsk. It played an important role in the preparation and conquest of Kazan by Ivan the Terrible. This fortified outpost founded in 1551 at the mouth of the Sviyaga river was the place of concentration of the Russian troops and necessary supplies for a subsequent siege of the capital of Kazan Khanate, acting as a support "camp" for the conquest. Undoubtedly, in order to protect this newly created settlement, serious defensive measures had to be taken in case of an enemy attack. An interesting source in this regard is the Russian Chronicle History of the 16th century. It summarizes the preparation and construction of this outpost, which served as the original source of information about this fortified settlement. In addition, the paper features new archaeological data related to the defensive structures of Sviyazhsk in the mid-16th century.

Keywords: archaeology, Middle Volga region, Middle Ages, Sviyazhsk fortress, fortification.

В процессе изучения фортификации, в том числе и конкретных памятников военного зодчества любого народа и государства, важную роль играют сообщения письменных источников. В них так или иначе отражены не только происходившие исторические события, но и приводятся некоторые сопутствующие им краткие описания, касающиеся различных поселений и их оборонительных сооружений. Здесь интересно обратиться к одному из интересных памятников градостроительства XVI в. - острову-граду Свияжску, расположенному в устье реки Свияги правого притока р. Волги, на высоком холме-останце площадью 62 гектара в 30 километрах к западу от г. Казани (рис. 1).

Наиболее интересным письменным источником, в котором отражено время основания Свияжска (Новгорода Свияжского), является Лицевой летописный свод XVI в. В нем под 1551 г. говорится, что Иван IV решил построить город: «...на Свияжьском устие на круглой горе; и сам бо государь, от Казани едучи (в 1550 г. - А.Г., Р.Х.), видел, што место стройно и пригоже быти городу...и умыслил государь городъ поставити на Свияге на устие, на Круглой горе, промежь Щучия озера и Свияги рекы...», и далее «И начинает государь и делу касается, призывает к собе диака своего Ивана Григорьева, сына Выродкова, и посылает его, а с ним детей боярскых, на Волгу в Углецкой уезд, в Ушатых вотчину, церквей и города рубити и в судех с воеводами на Низ вести, еже и бысть» (Лицевой летописный свод XVI века, 2014, с. 456-457). Затем уже в следующем 1551 г. «Месяца майа, 24 в неделю Всехъ святыхъ, царь Шигалей и воеводы пришли на Свиягу, и вылесчи воеводы великакого князя изъ судовъ, начаша лесъ сещи, где быти городу» (рис. 2), «и, очистив гору, пев молебная и воду освятя, и со кресты по стенному месту обошли» 
(Лицевой летописный свод XVI века, 2014, c. 472-473).

В случае, относящемся к нашей теме, довольно интересно дальнейшее сообщение: «Город же, которой сверху привезенъ, на половину тое горы стал, а другую половину воеводы и дети боярскые своими людми тотъ часъ зделали, велико бо бяше место, и свершили городъ въ четыре недели» (Лицевой летописный свод XVI века, 2014, с. 475) (рис. 3). Здесь прямо говорится, что переправленных вниз по Волге разобранных конструкций деревянных строений хватило только на то, чтобы частично (наполовину) застроить территорию острова. По-видимому, это в основном касается крепостных стен, предназначенных для защиты поселения по всему периметру. Отсюда можно сделать вывод, что или неточно было рассчитано необходимое количество конструкций изначально (проводилось в спешке), или заранее рассчитывалось добыть недостающие материалы для постройки оборонительных сооружений на месте. По нашему мнению, скорее всего, правильным будет последнее. Но тогда поздние утверждения о том, что весь (!) город был перевезен и собран на новом месте за четыре недели является просто «преувеличением», красивым мифом.

Крепостные стены Свияжска XVI в. всегда реконструировали в виде деревянных срубов-городней. Это часто отражается в музейных макетах и изобразительном материале ${ }^{1}$. Такая реконструкция вызывала некоторые сомнения, связанные с целесообразностью возведения подобных оборонительных конструкций по всему периметру поселения. Насколько точной и правильной она является? Нужно отметить, что в древности крепостные постройки всегда строились с учетом особенностей рельефа местности. Там, где это было необходимо, возводились сложные и мощные стены, башни и другие дополнительные сооружения. В местах же, защищенных самой природой, строились более «легкие», «простые» конструкции. Сотни и тысячи лет назад строители крепостей исходили из наличия имевшихся у них ресурсов и целесообразности, т. е. принципа разумной достаточности. Что же касается Свияжска, то ответ на данный

Подобная «вольность» в реконструкциях часто присуща многим художникам и современным реставраторам-реконструкторам по отношению к различным памятникам градостроительства и в первую очередь памятникам фортификации. вопрос дали археологические исследования последних лет, проведенные авторами на его территории в рамках реализации комплексного проекта «Культурное наследие - островград Свияжск и древний город Болгар».

Целью раскопок являлось исследование стратиграфии культурного слоя, остатков сооружений и ям, материальных остатков, а также поиск крепостных сооружений Свияжской крепости в северо-западной (три раскопа) и юго-восточной (один раскоп) частях острова (рис. 4).

Раскоп 1 площадью 78 кв. м был разбит в районе пересечения ул. Набережная р. Щуки и ул. Александровская, а также в 2 м от края островной террасы (Археологические исследования...). Помимо прочих объектов здесь было выявлено сооружение 4. Его следы в виде полосы шириной 80-90 см в верхней части были обнаружены в северной части раскопа на глубине 110-112 см от 0. Заполнением его являлась серо-желтая супесь и древесный тлен. Стенки ровные, слега скошены ко дну. Само сооружение представляло собой котлован для установки деревянной ограды. Оно датировалось временем не позже XVII в., о чем свидетельствовала стратиграфическая картина. Судя по стратиграфии, сооружение 4 перерезало более ранний котлован, чьи следы были выявлены только в западной и восточной стенках раскопа, в виде желтого суглинка. Он имел скошенные внутрь стенки и ровное дно. По-видимому, этот объект представлял собой котлован от крепостной стены середины XVI в., который был выявлен затем и в других местах раскопок. Кроме того, из этого же раскопа происходит и серебряная монета Ивана IV.

Раскоп 2 площадью 60 кв. м был разбит в 92 м к востоку - северо-востоку от предыдущего раскопа, в 2 м от края островной террасы и с севера примыкал к улице Набережная р. Щуки. Здесь после вскрытия третьего штыка на глубине 50-80 см от современной поверхности выявлено сооружение 2 в виде полосы шириной ок. 40 см, шедшей по линии запад-юго-запад - восток-северо-восток. Она располагалась в 8 м от края террасы и шла вдоль нее. Заполнением сооружения являлся желтый суглинок. В процессе его вскрытия было определено, что это котлован, вырытый для установки деревянных конструкций, имевший глубину ок. 200 см от современной поверхности и 150 см от уровня выявления. Стенки его были почти вертикальные, дно 
ровное. На уровне дна котлована были прослежены следы от вертикально забитых округлых бревен, установленных в ряд и сохранившихся в виде древесной трухи диаметром ок. 20 см и глубиной 30-35 см от уровня выявления (рис. 5). Судя по стратиграфии и заполнению, данный котлован соотносится со следами такого же объекта, частично выявленного в раскопе 1. По-видимому, они также являлись остатками тыновой ограды, установленной при основании Свияжска Иваном IV в 1551 г.

Следующий раскоп площадью 120 кв. м был разбит в 9 м к западу - юго-западу от раскопа 2 , а также в 2 м от края островной террасы. Он с севера примыкал к улице Набережная р. Щуки. В центральной части раскопа после вскрытия 4-го штыка было выявлено сооружение 5 в виде полосы шириной ок. 50 см, шедшей по линии запад-юго-запад - восток-северо-восток. Она располагалась в 6 м от современного края террасы и шла вдоль нее. Заполнением сооружения являлся желтый суглинок. В процессе его вскрытия было определено, что это котлован, вырытый для установки деревянных конструкций, имевший глубину 95-100 см от уровня выявления. Стенки его почти вертикальные, дно ровное. На уровне дна котлована были выявлены также следы от вертикально забитых бревен, установленных в ряд и сохранившихся в виде древесной трухи диаметром ок. 20 см и глубиной 30-35 см от уровня выявления (рис. 6). Судя по стратиграфии и заполнению, данный котлован соотносится со следами таких же объектов, обнаруженных в раскопе 1 и в раскопе 2. По нашему мнению, все эти вскрытые сооружения являются остатками тыновой ограды ${ }^{2}$ (рис. 7), установленной при основании Свияжска Иваном IV в 1551 г., которая защищала поселение с северо-запада. Никаких же следов от срубных конструкций в этой части острова выявлено не было. Нужно также отметить, что на этой полосе вдоль края террасы почти не было каких-либо строений на протяжении существования Свияжска. Здесь в основном существовали только огороды местных жителей, что позволило нам выявить остатки стены в почти не потревоженном состоянии.

В свою очередь, в юго-восточной части острова Свияжска, по ул. Набережная р. Свияги, также был заложен еще один раскоп. Он

\footnotetext{
Тыновая ограда (тын) - крепостная ограда из вертикальных плотно примкнутых бревен.
}

располагался на краю обрыва и имел площадь 68 кв. м. В результате проведенных исследований в основном были выявлены культурные напластования конца XVIII-XXI вв., а также зафиксированы остатки сооружений XVIII-XX вв.

Одно из них (Сооружение № 1) окончательно проявилось на уровне 7 пласта $(-100$ см от 0) в плане на площади $85 \times 400$ см в виде 13 деревянных вертикально врытых столбов диаметром от 15 до $30 \mathrm{~cm}$ (рис. 8). Столбы были вытянуты по линии юго-запад - северо-восток в одну линию. Заполнение вокруг столбов состояло из серо-коричневой плотной супеси с включением прокала. Стенки данного сооружения отвесные, дно относительно ровное, зафиксировано на уровне от -226 до -253 см от 0. Сооружение № 1 уходило в северо-восточную и юго-западную стенки раскопа. Находки из объекта были представлены стенками сосудов татарскорусского по образцу или в развитии белоглиняной керамики хорошего обжига с двусторонним ангобом и татарско-русского серого плохого обжига, а также придонной частью сосуда татарско-русского по образцу или в развитии белоглиняной керамики плохого обжига. Первоначально данная конструкция была принята за остатки деревянной стены, возведенной в XVIII в. Однако не исключено, учитывая аналогии с материалами раскопов в северо-западной части Свияжска, что время ее строительства относится также к сер. XVI в.

Проведенные нами исследования позволили по-новому обратить внимание на «феномен» основания и строительства укрепленного поселения на Свияжском холме. Пусть и небольшие по площадям раскопки и выявленный археологический материал, однако они дали нам возможность значительно скорректировать имевшуюся точку зрения на факт переправки по р. Волге целого города, что практически невозможно. По нашему мнению, были перевезены только основные деревянные конструкции, например, такие как крепостные проездные башни, примыкающие к ним участки срубных стен, а также некоторые духовные и гражданские постройки. Значительная же часть поселения-крепости строилась на месте из местных материалов. Что касается оборонительных сооружений, то, по-видимому, были привезены только конструкции с целью быстрой установки их в наиболее уязвимых для нападения частях 
холма, например в юго-западной, восточной и северо-восточной сторонах. Нужно также отметить - с древности и до нашего времени в остальных местах существуют довольно крутые склоны, по которым очень сложно подниматься, т. е. очень неудобные для возможного штурма. Именно вдоль них и была установлена тыновая ограда, что было совершенно достаточно в случае обороны. Материалы же для нее заготавливались на месте, благо дерева в то время более чем хватало. Сам же холм вряд ли не использовался людьми и пустовал до времени основания Свияжска. Об этом косвенно может свидетельствовать его удобное во всех отношениях местоположение, а также немногочисленные археологические находки, например Тверских пулов XV в. Один из них был найден в раскопе 2 и возможно датируется 1480 г. (рис. 9).

\section{ЛИТЕРАТУРА}

Археологические исследования 2016 г.: Болгар и Свияжск / авторы-составители: Ситдиков А.Г., Валиев Р.Р., Старков А.С. Казань: «Издательский дом «Казанская недвижимость», 2016. 40 с.

Лицевой летописный свод XVI века. Русская летописная история. Книга 20. 1541-1551 гг. М.: ООО «Фирма АКТЕОН», 2014. 562 c.

\section{Информация об авторах:}

Губайдуллин Айрат Маратович, доктор исторических наук, главный научный сотрудник Института археологии им. А.Х. Халикова Академии наук Республики Татарстан (г. Казань, Россия); airg_g@ mail.ru

Хамзин Радион Наилевич, научный сотрудник, Институт археологии им. А.Х. Халикова Академии наук Республики Татарстан (г. Казань, Россия); khrn80@yandex.ru

\section{REFERENCES}

Sitdikov, A. G., Valiev, R. R., Starkov, A. S. (comp.). 2017. Arkheologicheskie issledovaniia 2016 g.: Bolgar i Sviiazhsk (Archaeological Studies in 2016: Bolgar and Sviyazhsk). Kazan: "Kazanskaia nedvizhimost"” Publ. (in Russian).

2014. Licevoi letopisnyi svod XVI veka. Russkaia letopisnaia istoriia. Kniga 20. 1541-1551 gg. (The Illustrated Chronicle of the 16th century. Russian Chronicle History. Book 20. 1541-1551.). Moscow: "Firma AKTEON" (in Russian).

\section{About the Authors:}

Gubaidullin Airat M. Doctor of Historical Sciences, chief researcher, Institute of Archaeology named after A.Kh. Khalikov, Academy of Sciences of the Republic of Tatarstan, Butlerov St., 30, Kazan, 420012, the Republic of Tatarstan, Russian Federation; airg_g@mail.ru

Khamzin Radion N. Research associate, Institute of Archaeology named after A. Kh. Khalikov, Tatarstan Academy of Sciences. Butlerov Str., 30, Kazan, 420012, the Republic of Tatarstan, Russian Federation; khrn80@yandex.ru 


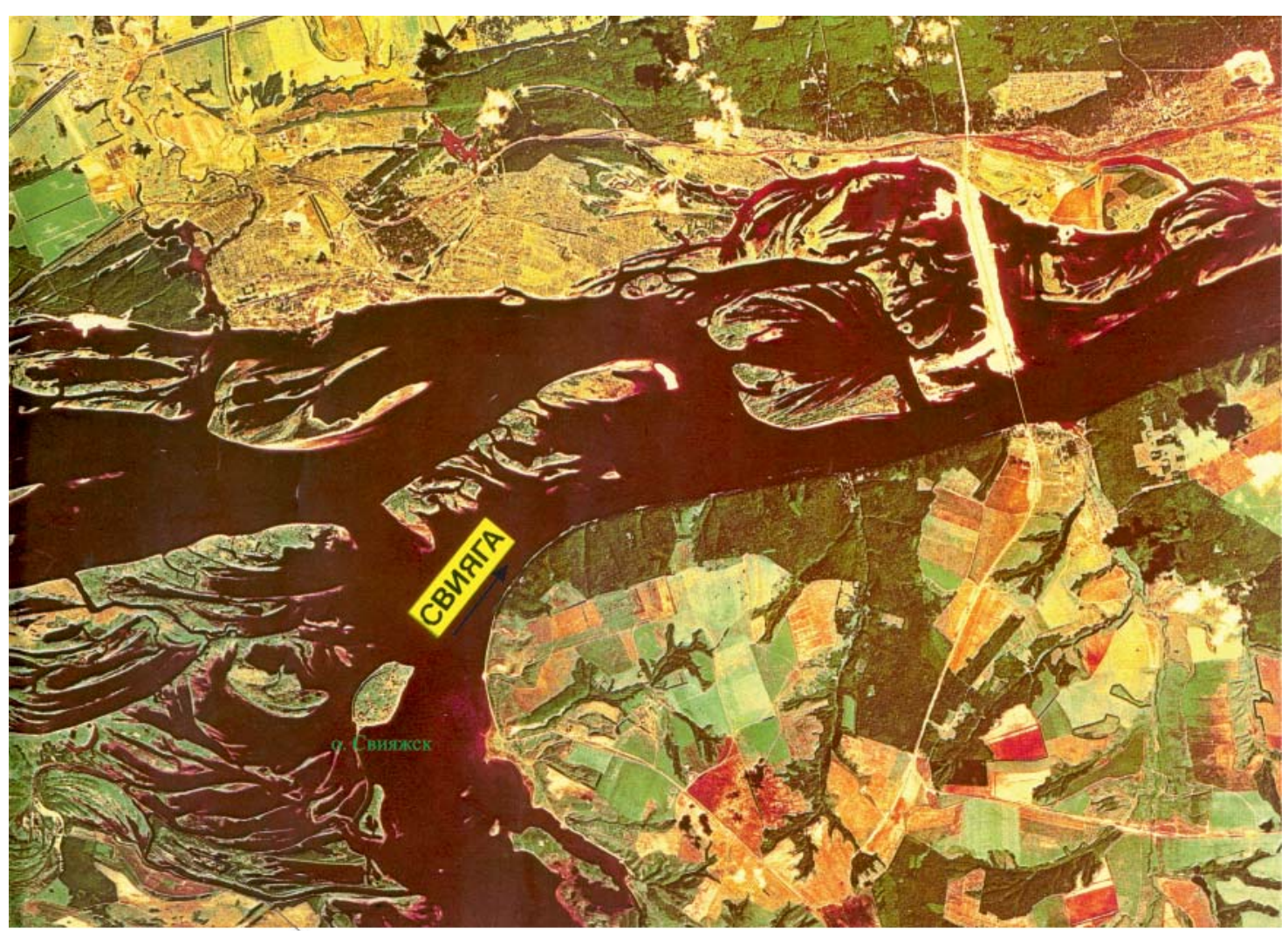

Рис. 1. Расположение острова-града Свияжск.

Fig.1. Location of the Island Town of Sviyazhsk.

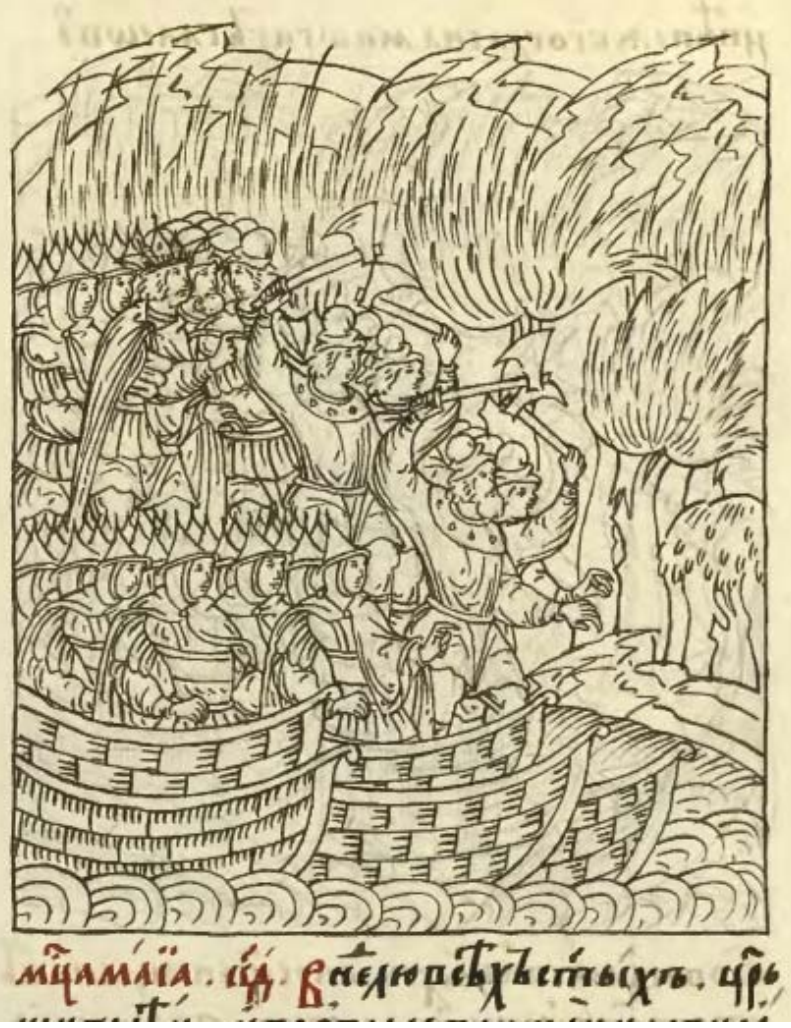

Рис. 2. Миниатюра из Лицевого летописного свода XVI в. C. 472.

Fig. 2. Miniature painting from the Illuminated Compiled Chronicle of the 16th century. P. 472.

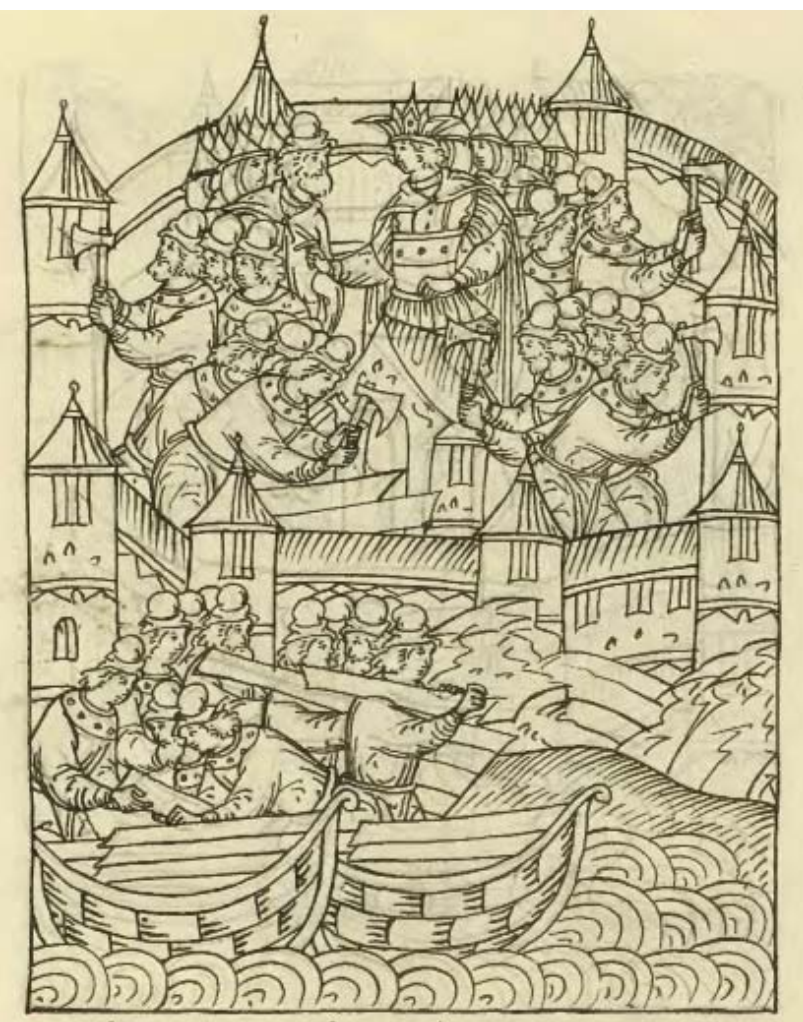

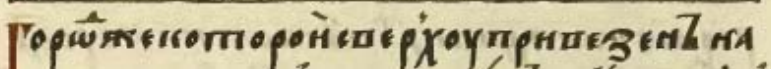

Рис. 3. Миниатюра из Лицевого летописного свода XVI в. C. 475.

Fig. 3. Miniature painting from the Illuminated Compiled Chronicle of the 16th century. P. 475. 


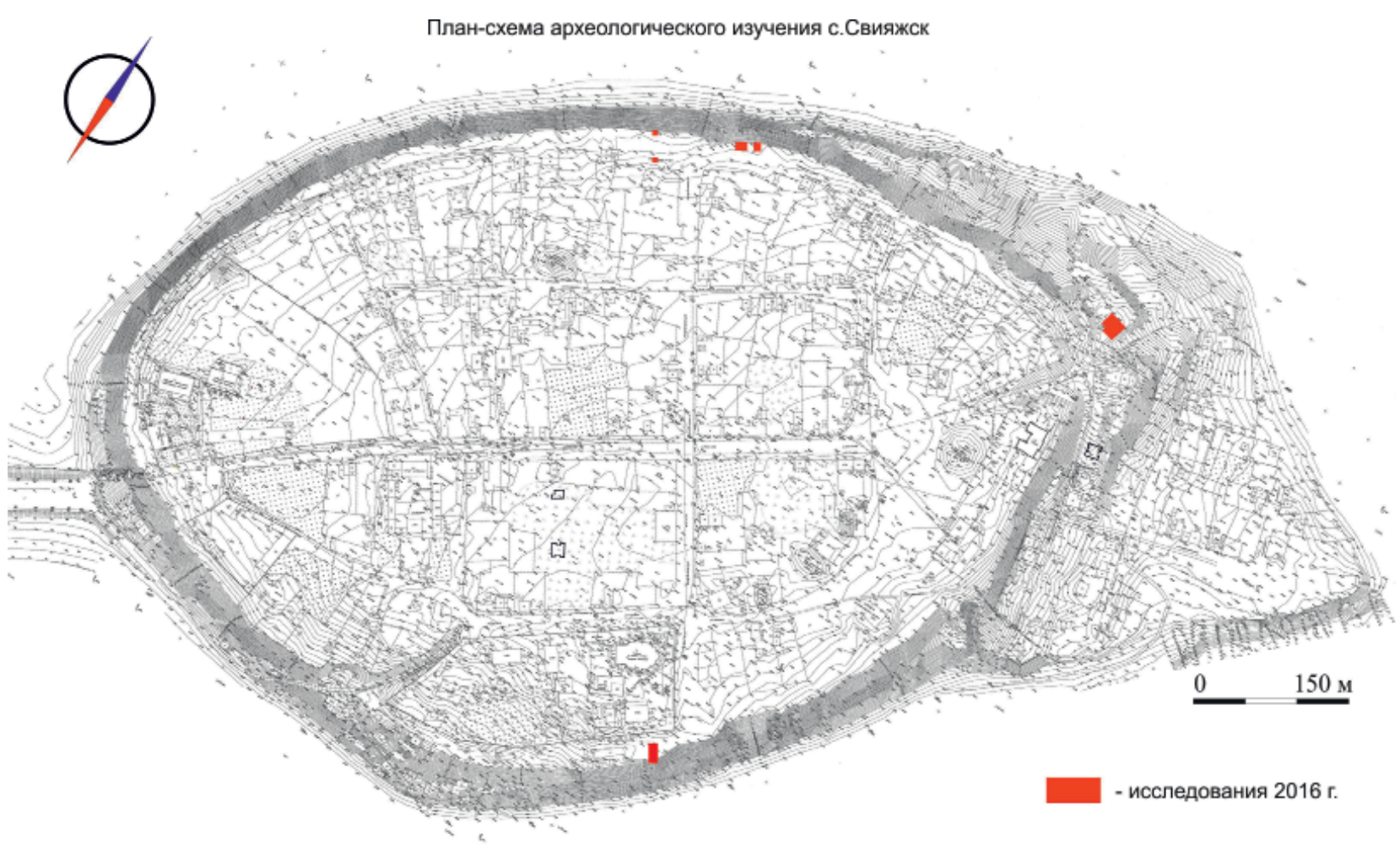

Рис. 4. План Свияжска с раскопами.

Fig.4. Plan of Sviyazhsk with excavations.

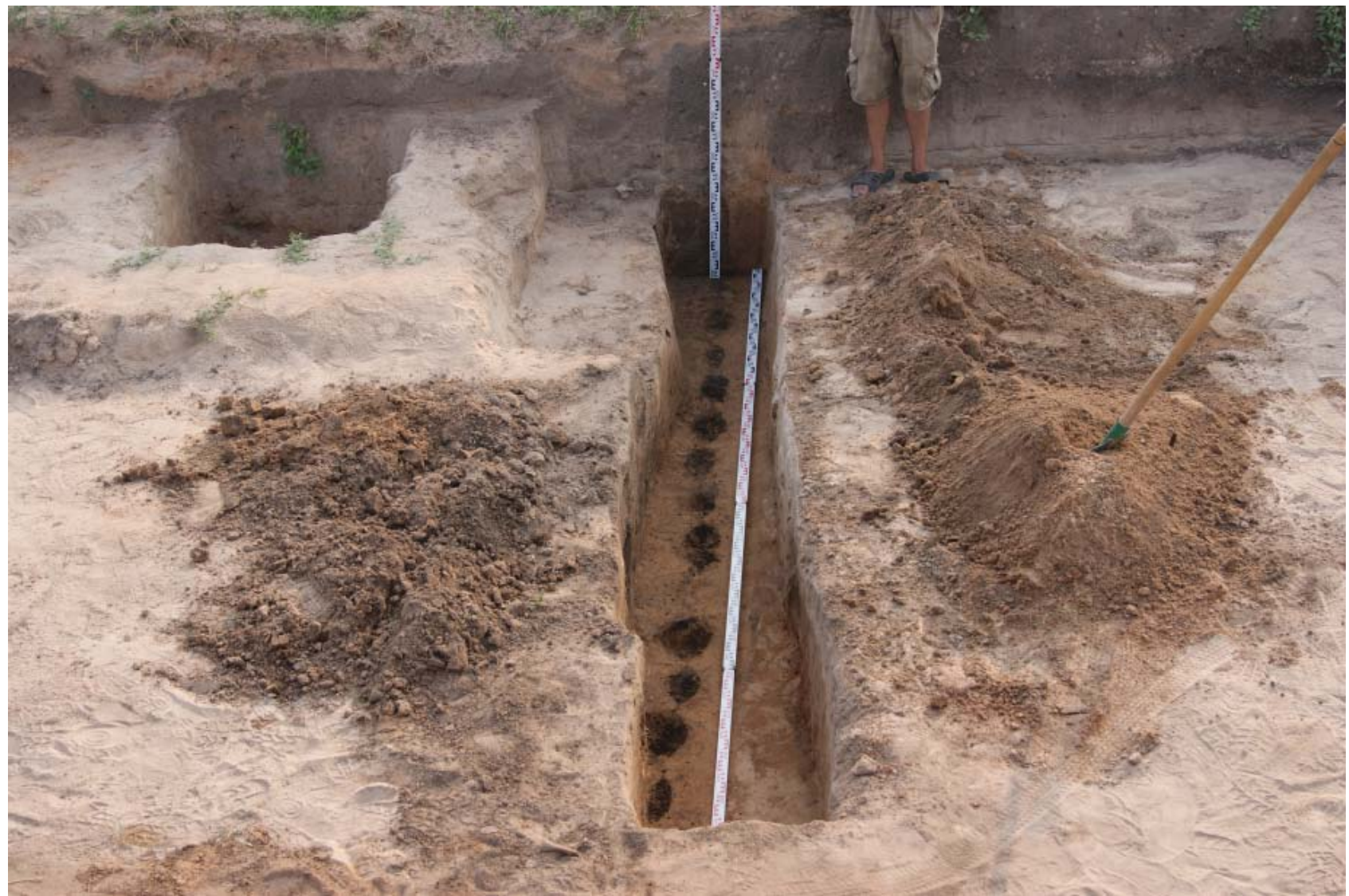

Рис. 5. Остатки тыновой ограды в северо-западной части Свияжска. Раскоп 2. Вид с северо-востока.

Fig.5. Remains of a lath fence in the north-western part of Sviyazhsk. Excavation 2. View from the north-east. 


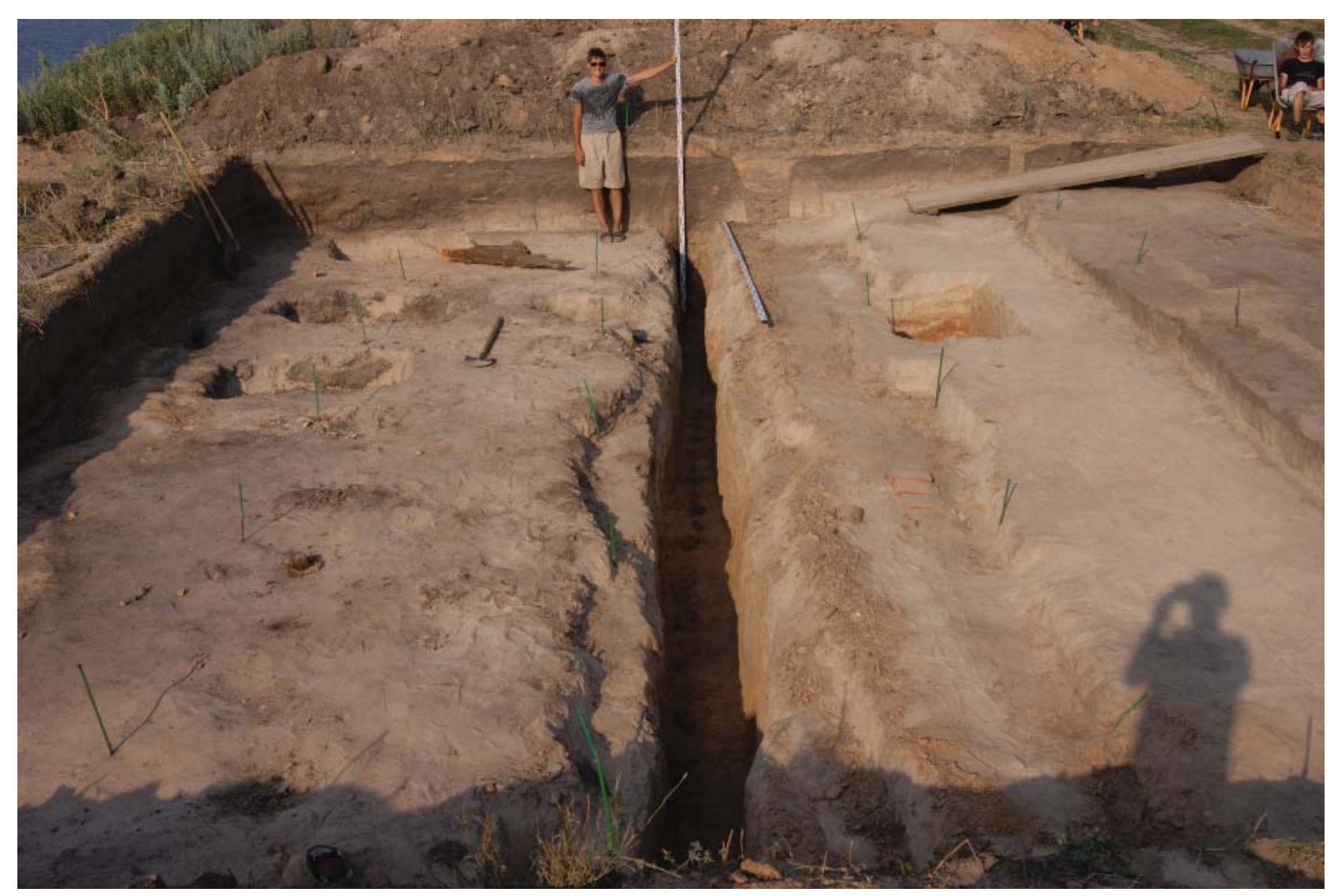

Рис. 6. Остатки тыновой ограды в северо-западной части Свияжска. Раскоп 3. Вид с юго-запада.

Fig.6. Remains of a lath fence in the north-western part of Sviyazhsk. Excavation 3. View from the south-west.

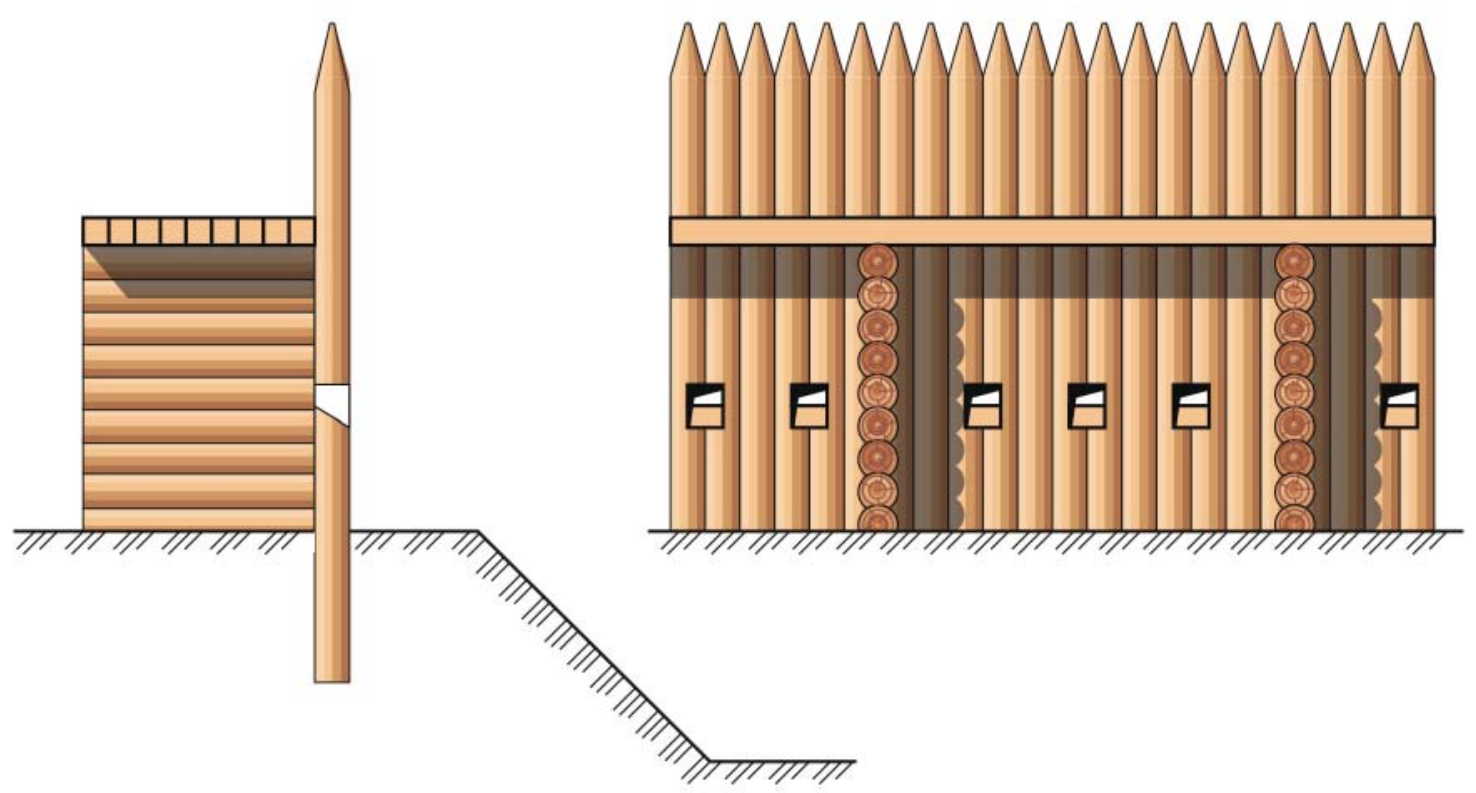

Рис. 7 Тыновая ограда.

Fig.7. Lath fence. 


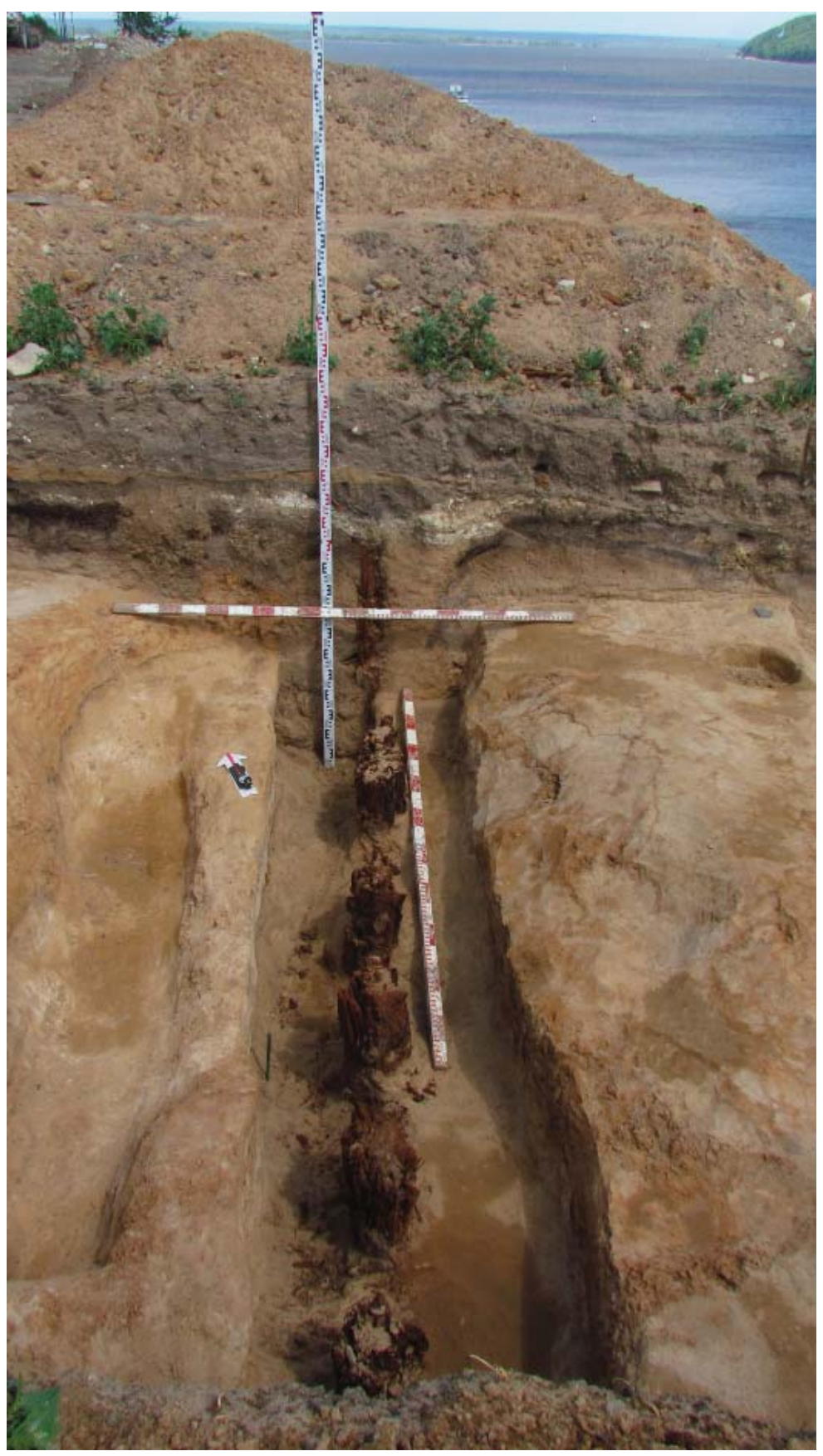

Рис. 8. Остатки тыновой ограды в юговосточной части Свияжска.

Вид с юго-запада.

Fig.8. Remains of a lath fence in the southeastern part of Sviyazhsk. View from the south-west.

Рис. 9. Тверской пул XV в. Fig. 9. Tverskoy pul, 15th c.

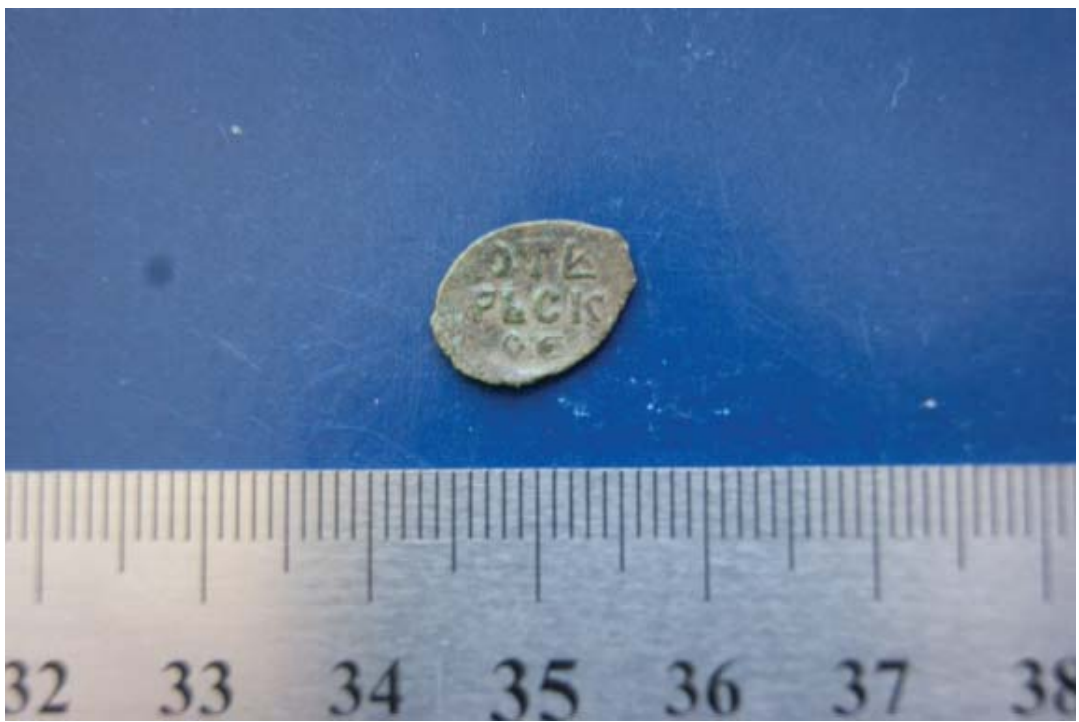

